\title{
The new method for assessing rock abrasivity in terms of wear of conical picks
}

\author{
Kamil Mucha \\ AGH University of Science and Technology, Poland
}

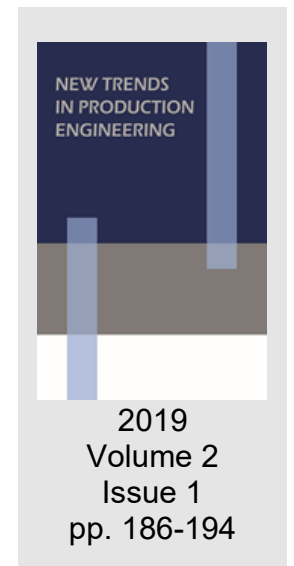

Date of submission to the Editor: 05/2019

Date of acceptance by the Editor: 07/2019

\section{INTRODUCTION}

In Polish as well as in many underground mines around the world, the drilling of roadway workings and the exploitation of longwall excavations is most often carried out by means of mechanical cutting, which involves direct operation with a cutting tool or a set of cutting tools on unmined rock. One of the basic groups of machines used in underground mining are cutting machines. In the case of tunnel excavation, roadheaders are used, whereas in the case of mining works, longwall shearers (Kotwica, 2018; Bołoz, 2018).

Among picks used on mining shearers, the most commonly used are conical picks. A pick is an element that is in direct contact with the cut rock and it is the one that is the quickest to destroy and thus needs to be replaced (Krauze et. al., 2015; Kotwica, 2018; Bołoz, 2018). There are different types of wear (Figure 1), but the worst case is a loss of the carbide insert (Figure 1d).

a)

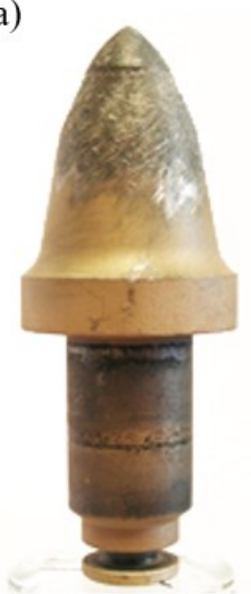

b)

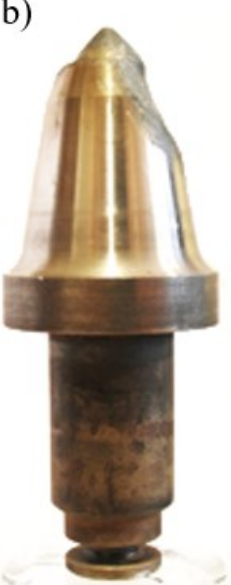

c)

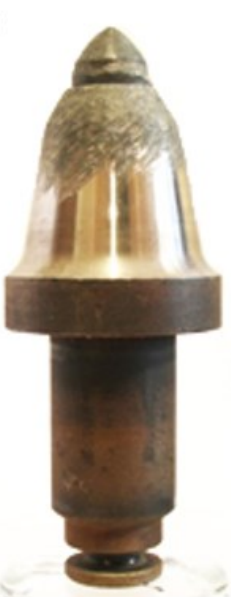

d)

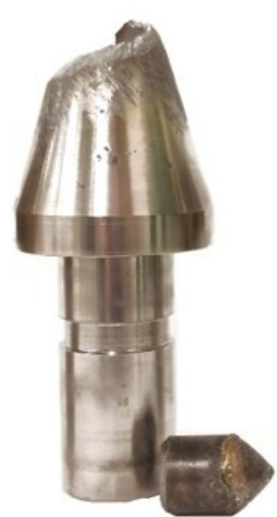

Fig. 1 Types of wear of a conical pick:

a - symmetrical, b - unsymmetrical, c - striping of the carbide insert, $d$ - carbide insert falling out

Currently, tunnel excavations, especially those providing access, are drilled in rocks with very unfavourable parameters. This applies first of all to large 
compactness and resistance to uniaxial compression of the rock mass. More and more often one encounters hard rocks, such as sandstone, which have a structure similar to homogeneous, which causes that their mining poses serious problems, and additionally they have good abrasive properties (Kotwica, 2018; Bołoz, 2018).

Currently, the most known and proven method of testing abrasivity is the CERCHAR abrasivity test. Based on it, the CAI indicator is determined. The CERCHAR abbreviation comes from the Centre d'Etudes et Recherches des Charbonnage de France - an institute which in 1980 was the first to develop a rock abrasivity test. The test is carried out by means of a sharpened pin made of steel with line inclination angle of the cone tip of $90^{\circ}$, pressed against the surface of the rock sample under a load of $70 \mathrm{~N}$, by means of which a groove $10 \mathrm{~mm}$ long is drawn (Fig. 2). The test is performed on surface of a small piece of rock cut away from a natural rough texture unmined rock. During the test, the sample is securely mounted in a clamp. A standard pin with a diameter of 11 $\mathrm{mm}$ and a length of $60 \mathrm{~mm}$ should be made of $115 \mathrm{CrV} 3$ steel with a hardness of 54-56 HRC. Generally, the CAI value is determined by the flattening or rounding of the tip of the pin caused by friction by the sample, which is measured under a microscope using an eyepiece micrometre. The diameter of the flattening is measured in four positions, each time the pin is rotated by $90^{\circ}$. On this basis, the CAl is calculated according to the following formula (1) (Plinninger et al., 2003; Käsling \& Thuro, 2010):

where:

$$
C A I=10 \cdot \frac{1}{n_{i}} \cdot \sum_{n_{o}} d[\mathrm{~mm}]
$$

$\mathrm{n}_{\mathrm{i}}$ - number of assays made;

$d-$ resultant mean flattening of the pin caused by friction on the sample.

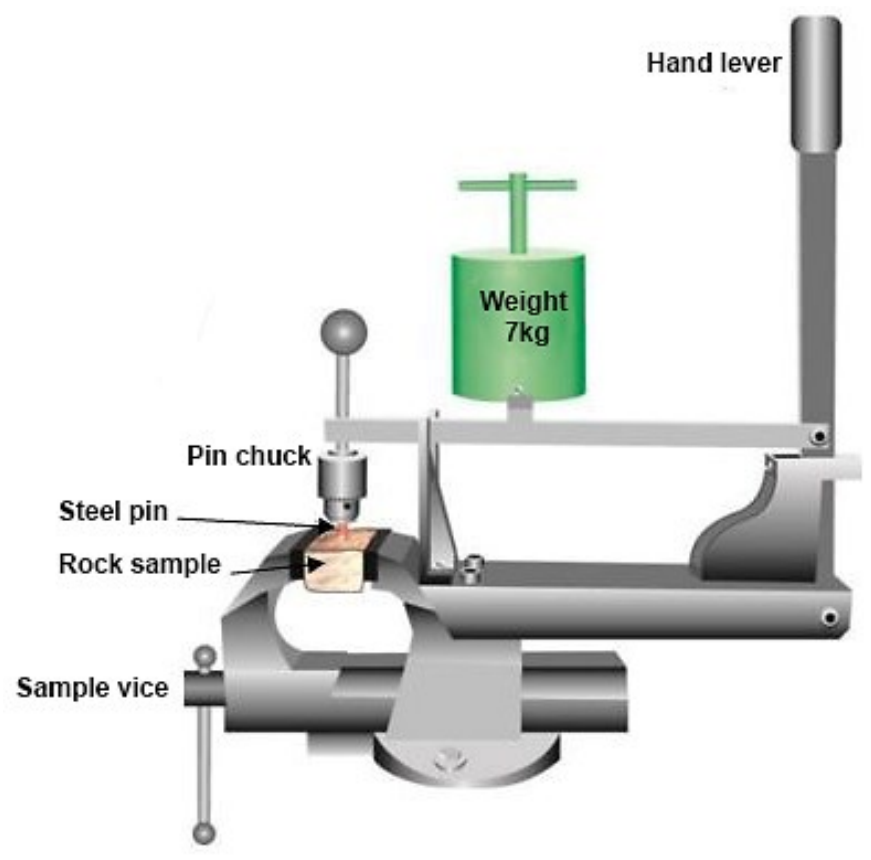


Based on many rock tests, abrasivity grades expressed in CAI values have been created. This classification is given in Table 1.

Table 1 The classification of abrasivity for CERCHAR abrasivity index

\begin{tabular}{ll}
\hline CERCHAR abrasivity index & Classification \\
\hline $0.3-0.5$ & not very abrasive \\
\hline $0.5-1.0$ & slightly abrasive \\
\hline $1.0-2.0$ & medium abrasive \\
\hline $2.0-4.0$ & very abrasive \\
\hline $4.0-6.0$ & extremely abrasive \\
\hline Source: (Plinninger \& Restner, 2008) &
\end{tabular}

The CERCHAR method, although it is simple and easy to perform, has one main disadvantage i.e. the measurement can be made only on small fragments of rock and that is why a large spread of the obtained results is possible, depending on the test site chosen by the operator for inhomogeneous and variable rock samples. Secondly, the accuracy of this method largely depends on the skills and experience of the person performing the test, who must have sufficient experience to identify the criteria for abrasion of the rock sample, and then perform the test according to these criteria. In addition, the measurement of the pin flattening diameter requires the use of a specialized microscope and can be difficult to determine in the case of unsymmetrical or one-sided flats (Mucha, 2019).

For this reason, the need arose to develop a new method for assessing rock abrasivity, which, although to some extent, will eliminate the above-mentioned disadvantages. The second reason was the lack of an unambiguous method of assessing the rock abrasivity normalized in Poland (Mucha, 2019).

\section{NEW METHOD FOR ASSESSING ROCK ABRASIVITY}

The method involves the assessment of the mass abrasive wear of a standard steel pin, in contact with a rock sample with a constant clamping force of $300 \mathrm{~N}$ and moving in a uniform motion around a circle at $50 \mathrm{rpm}$ for 8 minutes. The steel pin with a diameter of $8 \mathrm{~mm}$ and a length of $35 \mathrm{~mm}$ is made of S235 steel. Samples of rock for testing are taken in a form of cores with a diameter of $\Phi 70$ $\mathrm{mm}$ directly from a mining excavation (Mucha \& Krauze, 2018; Mucha, 2019). The test stand has been equipped with a gear motor unit with a $0.37 \mathrm{~kW}$ motor, on shaft of which the steel pin holder is mounted (Fig. 3a). The rock sample is mounted in a special holder, ensuring its immobilization during the test. An important advantage of the stand is the horizontal arrangement of the rock sample, which enables removal of loose rock grains from the road on which the pin moves. Thanks to this solution, the influence of loose grains on the wear of the standard pin and rock sample was eliminated. The steel pin together with the rock sample form a friction pair (Fig. 3b). Constant pressure of the rock sample to the surface of the pin is provided by a gravitational pressure system with six weights of $5 \mathrm{~kg}$ each. The pin speed and time are set using the touch 
panel (Fig. 3c). Thanks to the control system, the engine stops automatically after a set time (Mucha \& Krauze, 2018; Mucha, 2019).
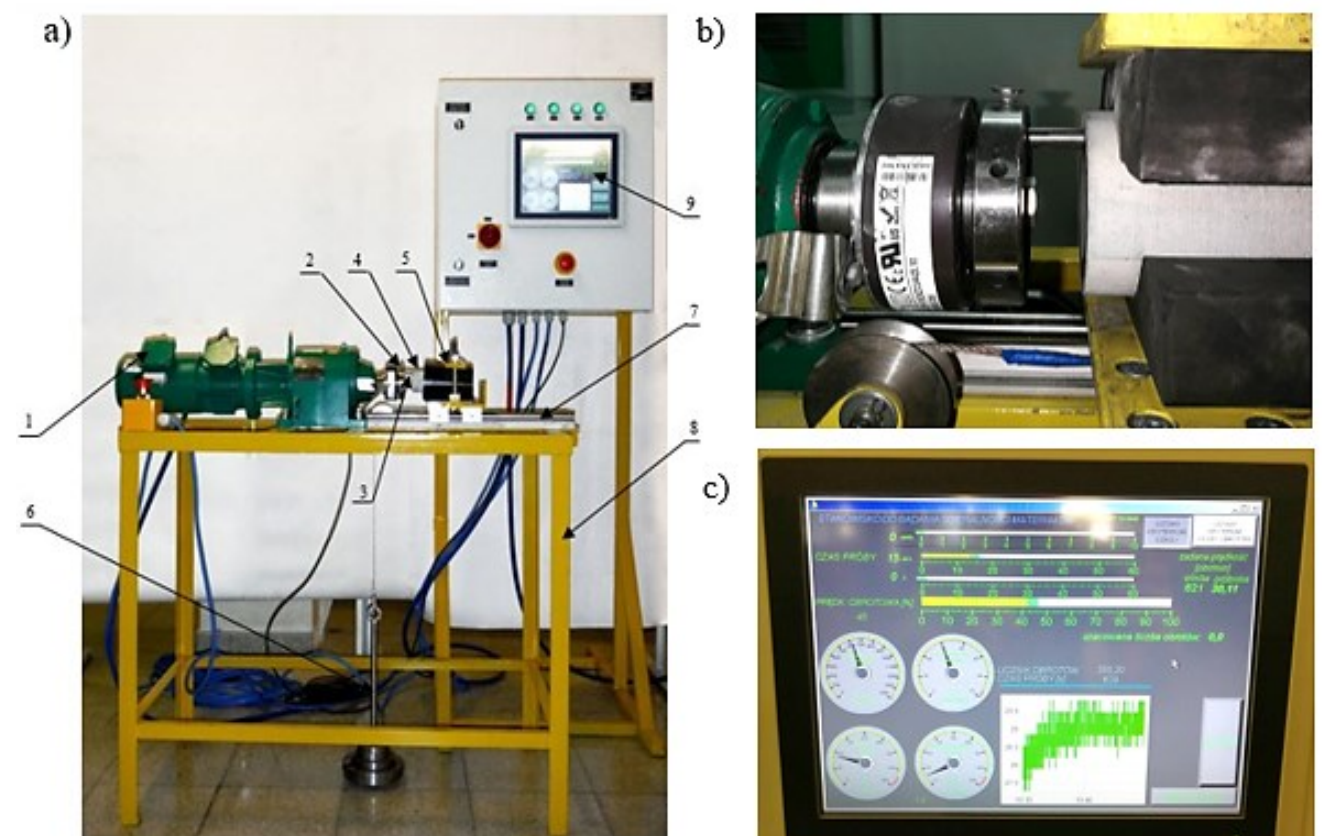

Fig. 3 Laboratory stand to assess rocks abrasivity:

a) general view, b) view of the friction pair, c) view of the control panel:

1 - drive unit, 2 - steel pin, 3 - pin holder, 4 - rock sample, 5 - rock sample holder,

$\mathbf{6}$ - pressure system, $\mathbf{7}$ - sliding system, 8 - supporting structure, $\mathbf{9}$ - control panel Source: (Mucha, 2019)

The weight of the pin as well as the sample is measured both before and after the test. The parameter characterizing the rock abrasivity is the abrasivity index $W_{z}$, which is defined as the ratio of the weight loss of the pin to the loss of the sample weight and is calculated using the following formula (2):

$$
W_{z}=\frac{M_{p a}}{M_{p i}}
$$

where:

$\mathrm{W}_{z}$ - abrasivity index,

$\mathrm{M}_{\mathrm{pi}}$ - weight loss of the sample, $\mathrm{g}$,

$\mathrm{M}_{\mathrm{pa}}$ - weight loss of the pin, $\mathrm{g}$.

where:

$$
M_{p a}=M_{p a b}-M_{p a a}
$$

where:

$M_{p a b}$ - weight of the pin before the test, $g$,

$M_{\text {paa }}$ - weight of the pin after the test, $\mathrm{g}$.

$$
M_{p i}=M_{p i b}-M_{p i a}
$$

where:

Mpib - weight of the sample before the test, $\mathrm{g}$,

Mpia - weight of the sample after the test, $g$.

Based on the results from over 600 tests, abrasivity grades expressed in the values of the $W_{z}$ index were determined. The classification is given in Table 2 . 
Table 2 Abrasivity classification using the AGH method

\begin{tabular}{ll}
\hline Abrasivity index $\mathbf{W}_{\mathbf{z}}[-]$ & Abrasivity Classification \\
\hline$<0.1$ & negligible \\
\hline $0.1-0.5$ & insignificant \\
\hline $0.5-0.9$ & very low \\
\hline $1.0-1.9$ & low \\
\hline $2.0-2.9$ & medium \\
\hline $3.0-3.9$ & high \\
\hline $4.0-5.0$ & very high \\
\hline$>5.0$ & extreme \\
\hline
\end{tabular}

Source: (Mucha, 2019)

\section{THE TEST PROCEDURE AND RESULTS}

Using the developed method, it was decided to check the abrasivity of the most common gangue rocks in Polish hard coal mines. Rock samples from underground workings of five mines were collected for research, drilling in the mines is carried out by mechanical cutting using shearers. Samples were taken from mines located in Upper Silesia and Lesser Poland, i.e. from the regions with the largest hard coal resources in Poland (Fig. 4).
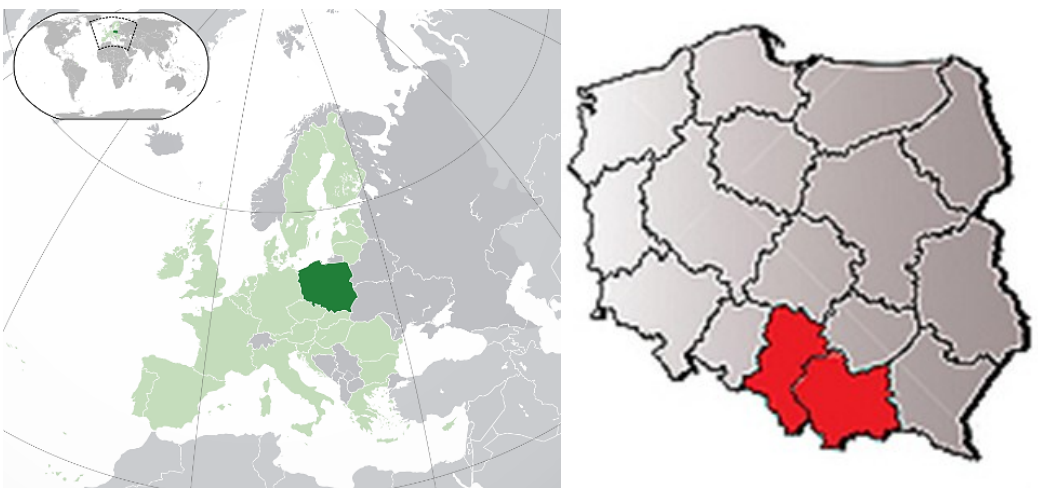

Fig. 4 Location of the area from which rock samples for research were taken Source: (Wikipedia 2019, Megapixl 2019)

A total of 12 samples were collected, each from other excavation, which was given the appropriate markings. Among the samples taken were sandstones, claystones, mudstones and shales. For each sample, the abrasivity index $\mathrm{W}_{\mathrm{z}}$ (Fig. 5) and uniaxial compression strength (UCS) were determined and chemical composition analysis using the XRF method was carried out.
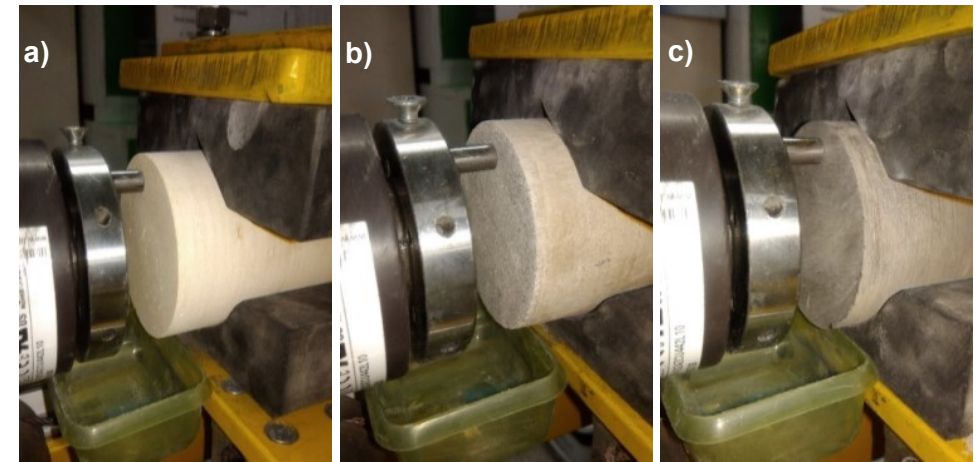

Fig. 5 View of selected samples during the abrasivity test using the AGH method:

a) sandstone, b) claystone, c) mudstone 
A summary of the results obtained is presented in Table 3.

Table 3 Summary of test results

\begin{tabular}{|c|c|c|c|c|c|c|c|}
\hline No. & Rock type & $\begin{array}{c}\text { Sample } \\
\text { code }\end{array}$ & $\begin{array}{l}\text { UCS } \\
\text { [MPa] }\end{array}$ & $\begin{array}{l}\mathrm{SiO}_{2} \\
{[\%]}\end{array}$ & $\begin{array}{c}\mathrm{Al}_{2} \mathrm{O}_{3} \\
{[\%]}\end{array}$ & $\mathbf{W}_{\mathbf{z}}[-]$ & $\begin{array}{c}\text { Abrasivity } \\
\text { Classification }\end{array}$ \\
\hline 1 & $\begin{array}{l}\text { medium- } \\
\text { grained } \\
\text { sandstone }\end{array}$ & S1 & 22.4 & 76.3 & 16.5 & 2.4 & medium \\
\hline 2 & $\begin{array}{l}\text { fine-grained } \\
\text { sandstone }\end{array}$ & S2 & 64.6 & 66.1 & 11.8 & 1.5 & low \\
\hline 3 & shale & S3 & 9.5 & 64.4 & 29.0 & 0 & negligible \\
\hline 4 & $\begin{array}{l}\text { medium- } \\
\text { grained } \\
\text { sandstone }\end{array}$ & MS1 & 29.4 & 83.5 & 6.7 & 3.8 & high \\
\hline 5 & claystone & MS2 & 24.7 & 50.4 & 28.0 & 0.2 & insignificant \\
\hline 6 & $\begin{array}{c}\text { fine-grained } \\
\text { sandstone }\end{array}$ & MS3 & 19.4 & 75.3 & 11.1 & 1.7 & low \\
\hline 7 & claystone & MS4 & 28.4 & 62.5 & 28.1 & 0.3 & insignificant \\
\hline 8 & mudstone & J1 & 12.2 & 58.8 & 27.9 & 0 & negligible \\
\hline 9 & mudstone & $\mathrm{J} 2$ & 12.8 & 62.3 & 28.2 & 0 & negligible \\
\hline 10 & $\begin{array}{l}\text { variegated } \\
\text { sandstone }\end{array}$ & J3 & 20.8 & 72.2 & 15.3 & 1.6 & low \\
\hline 11 & $\begin{array}{c}\text { fine-grained } \\
\text { sandstone }\end{array}$ & P1 & 30.1 & 71.7 & 15.5 & 1.2 & low \\
\hline 12 & mudstone & B1 & 18.1 & 59.1 & 28.0 & 0 & negligible \\
\hline
\end{tabular}

\section{ANALYSIS OF TEST RESULTS}

Rocks that have been taken from mine excavations are characterized by diverse abrasive and strength properties. The first relationship that was decided to be check was whether the abrasivity index $W_{z}$ depends on the value of uniaxial compression strength UCS. As shown in Figure 6, the $W_{z}$ abrasivity index shows a weak correlation with UCS within this group of rocks.

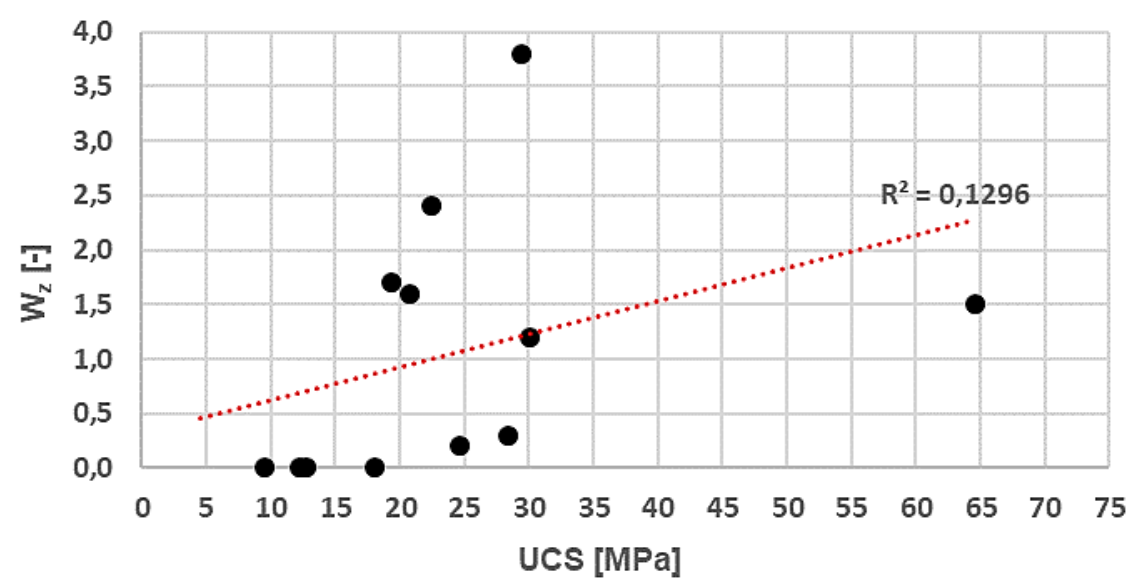

Fig. 6 The dependence of the $W_{z}$ abrasivity index on UCS

However, many authors, e.g. (Yaşar \& Yilmaz, 2016) showed the same correlation between CAI from the CERCHAR method and the UCS value. This weak correlation indicates that it is not possible to estimate the abrasive properties of rocks on the basis of UCS values. For example, if you consider two rocks that have exactly the same UCS value, and one of them will have a higher 
abrasivity index, it will cause more tool wear. Therefore, when selecting the type of cutting tool, both indicators should be taken into account.

A definitely stronger correlation was observed between the abrasivity index $\mathrm{W}_{\mathrm{z}}$ and the chemical composition of the studied rocks (Figures 7 and 8). The most numerous, in terms of quantity, is the percentage of $\mathrm{SiO}_{2}$, i.e. the so-called silica. The fact that the more silica in the rock, then the rock has better abrasive properties, was known a long time ago. This is confirmed by the research of many scientists, incl. (Torrijo et al., 2019, Yarali et.al., 2008). For the group of collected rocks, the $\mathrm{R}^{2}$ determination coefficient was $78.9 \%$ (Fig. 7), which indicates a strong correlation of these two parameters.

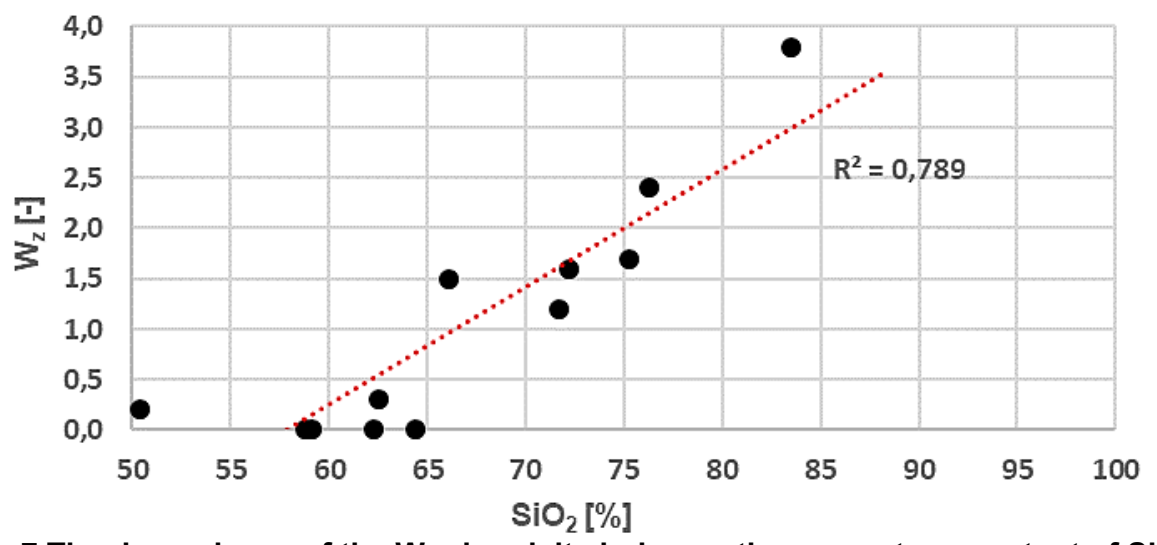

Fig. 7 The dependence of the $\mathrm{W}_{\mathrm{z}}$ abrasivity index on the percentage content of $\mathrm{SiO}_{2}$

The chemical compound of the second largest quantity turned out to be aluminium oxide. Its percentage content also showed a strong correlation with the value of the $\mathrm{W}_{\mathrm{z}}$ index and for the collected rocks $\mathrm{R}^{2}$ determination coefficient was $82.8 \%$ (Fig. 8 ).

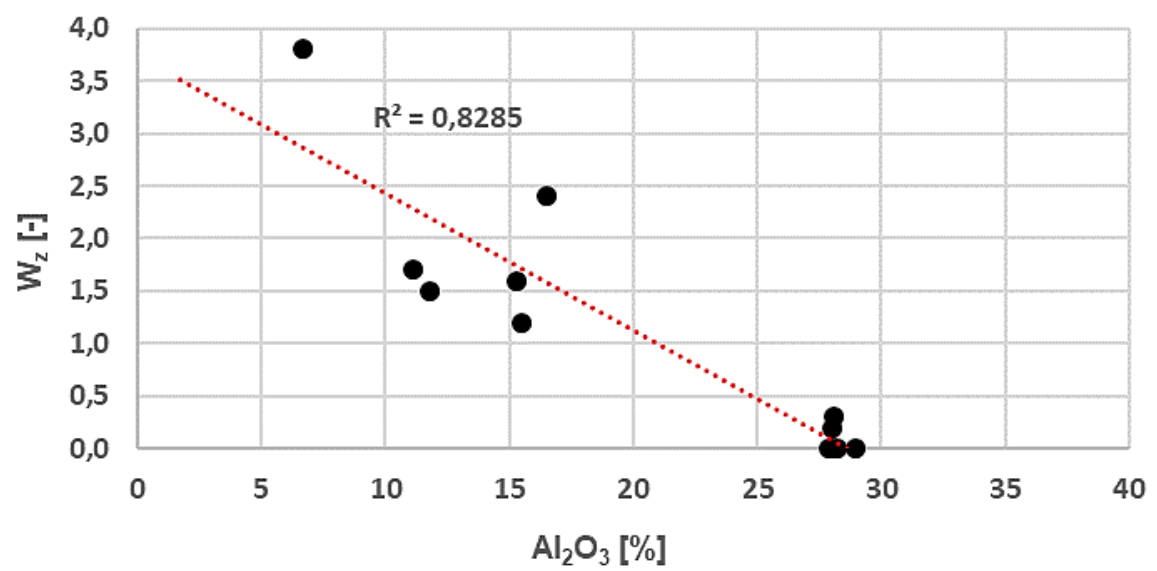

Fig. 8 The dependence of the $\mathrm{W}_{\mathrm{z}}$ abrasivity index on the percentage content of $\mathrm{Al}_{2} \mathrm{O}_{3}$

However, in this case the situation is reversed compared to silica and the more aluminium oxide, the smaller the value of the $\mathrm{W}_{\mathrm{z}}$ index. Such a strong correlation between $\mathrm{Al}_{2} \mathrm{O}_{3}$ and the abrasivity index $\mathrm{CAl}$ was also noticed by the authors of the publication (Torrijo et al., 2019). 


\section{CONCLUSION}

When selecting cutting machine picks, taking into account the physical and mechanical properties of rocks, attention is paid mainly to the uniaxial compression strength (UCS). Very rarely, the user (mine) takes into account the rock abrasivity. For this reason, methods for determining rock abrasivity are not widely used. Currently, the most known method is the CERCHAR abrasivity test. The innovative method of assessing abrasivity of rocks, presented in this article, distinguishes itself from other with simplicity, collecting rock samples directly from mine excavation without labour-intensive and time-consuming preparation for testing and the fact that it eliminates the impact of loose grains on the wear of the pin as well as the rock sample.

The research described in this article allowed the use of this method of rock abrasivity assessment to determine the abrasivity indexes of rocks most abundant in the currently cut tunnel excavations in Polish hard coal mines. These rocks include sandstones, claystones, mudstones and shales. Thanks to a careful analysis of the results, the relationship between the new abrasivity index $\mathrm{W}_{\mathrm{z}}$ and the uniaxial compression strength (USC), the percentage of $\mathrm{SiO}_{2}$ and $\mathrm{Al}_{2} \mathrm{O}_{3}$ was obtained.

The results obtained are promising and show that the proposed method has great potential to carry out tests related to the assessment of rock abrasivity. However, it should be noted that it is still being refined and requires further testing.

\section{ACKNOWLEDGEMENTS}

Works financed from the dean's grant at the Faculty of Mechanical Engineering and Robotics at the AGH University of Science and Technology under contract number 16.16.130.942.

\section{REFERENCES}

Bołoz $Ł$. (2018). Results of a study on the quality of conical picks for public procurement purposes. In: Proceedings of the international conference on Human safety in work environment: operating machinery and equipment: Integrated Management Systems: Quality - Environment - Safety, 23-27 October 2018, Gdańsk Nynashamn - Sztokholm - Tallin - Sztokholm - Nynashamn - Gdańsk, pp. 687693.

Käsling H., Thuro K. (2010). Determining abrasivity of rock in the laboratory. Engineering Geology. Technische Universität München, Germany, pp. 19731980.

Kotwica K. (2018). Atypical and innovative tool, holder and mining head designed for roadheaders used to tunnel and gallery drilling in hard rock. Tunnelling and Underground Space Technology, 82, pp. 493-503.

Krauze K., Bołoz Ł., Wydro T. (2015). Parametric factors for the tangential-rotary picks quality assessment. Archives of Mining Sciences, 60(1), pp. 265-281.

Megapixl (2019). Poland provinces maps: https://www.megapixl.com/polandprovinces-maps-illustration-31515681

Mucha K., Krauze K. (2018). Planning of experiment for laboratory tests on rock abrasivity. Mining - Informatics, Automation and Electrical Engineering 3, pp. 1724. 
Mucha K. (2019). Ścierność skał w aspekcie prognozowania zużycia noży kombajnowych. (Rock abrasivity in terms of forecasting the abrasive wear of cutting picks). PhD Thesis, AGH University of Science and Technology, Kraków, Poland.

Plinninger R. J., Restner U. (2008). Abrasivity testing, Quo Vadis? - A commented overview of abrasivity testing methods. Geomechanics and Tunnelling 1(1), pp. 61-70.

Plinninger R.J., Kasling H., Thuro K., Spaun G. (2003). Testing conditions and geomechanical properties influencing the Cerchar abrasiveness index (CAI) value. International Journal of Rock Mechanics and Mining Sciences, 40, pp. 259263.

Torrijo E.J., Garzón-Roca J., Company J., Cobos G. (2019). Estimation of Cerchar abrasivity index of andesitic rocks in Ecuador from chemical compounds and petrographical properties using regression analyses. Bulletin of Engineering Geology and the Environment 78(4), pp. 2331-2344.

Wikipedia (2019). Poland in Europe: https://commons.wikimedia.org/wiki/File:EUPoland.svg

Yarali O., Yaşar E., Bacak G., Ranjith P.G. (2008). A study of rock abrasivity and tool wear in coal measures rocks. International Journal of Coal Geology, 74, pp. 5366.

Yaşar S., Yilmaz A.O. (2016). Tool wear prediction with different models for medium strength rocks. In: $13^{\text {th }}$ International Conference Underground Construction, Prague 2016, CEK CUM., 23-25 May 2016, 1(1), pp.1-10.

\begin{abstract}
.
During the exploitation of mineral raw materials, a cutting tool is an element that is directly in contact with the unmined stone being cut. The most commonly used cutting tools include conical picks. The increasing pressure to reduce mining costs causes an increasing demand for affordable and reliable ways to increase the reliability of mining machines. Abrasive wear is the most common process affecting the wear of shearer picks, hence a good and simple laboratory method for assessing rocks abrasivity is needed. The new method was developed in the aspect of selection of conical picks with appropriate protection of the pick working part, increasing its durability. The method involves the assessment of mass abrasive wear of a standard steel pin and rock sample, and the determination of the abrasivity index $\mathrm{W}_{\mathrm{z}}$ of the tested rock, as the ratio of the mass loss of the steel pin to the mass loss of the rock sample. The article presents the procedure of conducting tests, construction of a laboratory test stand and the use of the developed method to assess the abrasivity of gangue rocks occurring in the currently cut tunnel excavations of Polish hard coal mines.
\end{abstract}

Keywords: test method, assessment of abrasivity, conical picks, abrasive wear, underground mining 